\title{
EDITORIAL
}

\section{INTERNATIONAL SECURITY COMMUNITY AT THE CROSSROADS}

For some time already, the international security community has been at a crossroads and looking for new right directions. The established operational guidelines have changed, and in some areas, it seems that they simply no longer exist. There are many factors which have had an effect on the relatively high level of security we have witnessed in the last few years. The financial crisis, which started to show its teeth in 2008 and 2009, has seriously changed the European armed forces, their structure, organization and development. Many comforted themselves that this does not constitute a significant problem, since we are relatively safe. Public opinion surveys in Slovenia revealed that most of all, people feel threatened by natural disasters and socio-economic situation. However, gradually but relatively quickly, everything has changed. In the spring of 2014, Crimea held a referendum on its annexation to the Russian Federation. The rattling of weapons began, provoking different reactions in the international community and resulting in altered relations between NATO and Russia. These changes were also discussed at the July NATO Summit in Warsaw.

Two years earlier, in 2012, the media increasingly reported on the soaring migration problems in the Mediterranean Sea and difficulties suffered by Italy due to those phenomena. By the end of last year, migrations from the Southeast reached unimaginable proportions and gave a profound shock to the foundations of the European Union. Some terrorist attacks in European cities, which were said to be organized and carried out by migrants, had a significant impact on the altered understanding of the new (in)security. Some experts adopted a scientific approach to the new understanding of safety. The Defence Research Centre of the Faculty of Social Sciences, for example, published the results of a survey on the opinions of the Slovenian public regarding safety, which was carried out in 2015/2016. Among other things, the findings show that the recent migrant crisis has affected the Slovenian public, which perceives mass migrations as well as illegal and economic migrants as an important reason of concern. The authors of the survey observed a marked 
increase in the acceptance of the idea that in the protection of borders from illegal crossings, the Police are assisted by the Slovenian Armed Forces. A significantly high number of people also agreed with the idea that the armed forces should help in the fight against terrorism which, before the occurrence of mass migrations, was unthinkable. According to the authors of the survey, in the last three years, the support of the Slovenian public to the participation of Slovenia in international operations and missions has also grown by more than 20 percent. In addition, the proportion of the public which supports proposals to increase the defence budget has gone up. But will it actually increase, and how soon?

We are still waiting for the new European defence strategy. We are anticipating new solutions, agreements between the decision-makers, etc.

In the meantime, different authors went through various experiences. Some of them have decided to share them with our readers.

In his article Fourth Generation Warfare: Geopolitical Framework to Slovenian Security (Part 1),Viktor Potočnik explores the issue of how geopolitics impacts the global security situation, what are the contemporary security risks and how they can affect Slovenia. In ensuring national security, the Slovenian Armed Forces play an important role. Consequently, Potočnik raises the question of whether they have a sufficient level of readiness to withstand potential risks, and presents the facts which he believes can have a key influence on the Slovenian national security.

Cyber threats represent one of the most modern forms of security threats. In the previous issue of the Contemporary Military Challenges, Vinko Vegič provided the definition of cyber threats. This issue continues this theme with the article NATO and Cyber Deterrence, written by Staša Novak. According to her, NATO is de facto already pursuing certain elements of cyber deterrence based on strong defence, declaratory policy and responsive measures. However, responsive measures are not NATO offensive cyber capabilities, but the possibility of a collective defence response to a cyber attack, which implies a response with all available means.

The increased number of migrants on their way to a better future has surprised many people in the Balkans, although numerous institutions and individuals had warned of this possibility before. Some experiences and responses of Slovenia's neighbour, Hungary, are presented in an article by József Padányi and László Földi, titled Lessons Learned for the Hungarian Defence Forces from the Deployment of Engineer Obstacles during the 2015 Europe-Wide Mass-Migration Emergency. The article focuses mainly on the activities of the Hungarian armed forces.

Metodi Hadji-Janev and Marija Jankuloska point out that the region of SouthEastern Europe has witnessed some examples of terrorist attacks and observe that the use of drones for countering global terrorism proved to be effective. Their article 
The Challenges of Drone Usage by Southeast European Countries examines the possibilities of their use in the home region.

In his article titled Islamic State of Iraq and the Levant and the International Fight against It, József Kis-Benedek discusses the origins of this phenomenon and its manifestations in various Middle East countries, as well as the response of those countries and other international actors who share an interest in this part of the world. He also calls attention to the question of the Kurds and the emergence of volunteer fighters who are coming to Syria and Iraq to fight.

The Battalion Battle Group and the evaluation of its training is the subject of the article titled Battle Group Training Cycle, in which Aleš Avsec compares the methods of training of these units in the Slovenian Armed Forces with the training of similar units in the United States of America. Is it even possible to compare two countries which are that different? 